\title{
NOTES
}

\section{TMC-89A and B, New Proteasome Inhibitors from Streptomyces sp. TC 1087}

\author{
Yutaka Koguchi, Maki Nishio, Shin-ICHI SuzUKI, \\ Kohei Takahashi, Tetsuo OHNUKI* and \\ SABURO Komatsubara \\ Department of Basic Technology, \\ Discovery Research Laboratory, Tanabe Seiyaku Co., Ltd., \\ 2-50 Kawagishi-2-chome, Toda-shi, \\ Saitama 335-8505, Japan
}

(Received for publication April 5, 2000)

The ubiquitin/proteasome system is a major pathway of selective protein degradation in eukaryotic cells. The system degrades a number of important cellular proteins such as oncogene products, cyclins, and transcriptional factors. The target proteins are conjugated to polypeptide ubiquitin, and then degraded by a proteasome in an ATP dependent manner ${ }^{1)}$. The catalytic core of the proteasome is the $20 \mathrm{~S}$ proteasome. New $20 \mathrm{~S}$ proteasome inhibitors would contribute to further understanding of the system ${ }^{2 \sim 4)}$. In the course of our screening program, we have isolated several classes of $20 \mathrm{~S}$ proteasome inhibitors including (i) the novel cyclic peptides, TMC-95s, and (ii) the new members of $\alpha^{\prime}, \beta^{\prime}$-epoxyketone containing peptides, TMC-86s and TMC-96, from microbial metabolites ${ }^{5 \sim 8)}$. Our recent search resulted in the isolation of TMC-89A and $\mathrm{B}$, new members of the $\alpha^{\prime}, \beta^{\prime}$-epoxyketone containing peptides, from a microbial metabolite. We describe here the taxonomy of producing strain, production, isolation, structural studies,

Table 1. Cultural characteristics of strain TC 1087.

\begin{tabular}{|c|c|c|}
\hline Medium & & TC 1087 \\
\hline $\begin{array}{l}\text { Yeast extract-malt extract agar } \\
\text { (ISP No.2) }\end{array}$ & $\begin{array}{r}\text { G: } \\
\text { AM: } \\
\text { R: } \\
\text { S: }\end{array}$ & $\begin{array}{l}\text { Good } \\
\text { Abundant, Olive gray }(9-16-1)^{*} \\
\text { Dark brownish gray }(3-12-1) \\
\text { Pale yellowish brown }(7-18-2)\end{array}$ \\
\hline $\begin{array}{l}\text { Oatmeal agar } \\
\text { (ISP No.3) }\end{array}$ & $\begin{array}{r}\text { G: } \\
\text { AM: } \\
\text { R: } \\
\text { S: }\end{array}$ & $\begin{array}{l}\text { Good } \\
\text { Abundant, Brownish gray }(7-15-1) \\
\text { Brownish black }(3-11-1) \\
\text { Grayish brown (5-16-2) }\end{array}$ \\
\hline $\begin{array}{l}\text { Inorganic salts-starch agar } \\
\text { (ISP No.4) }\end{array}$ & $\begin{array}{r}\text { G: } \\
\text { AM: } \\
\text { R: } \\
\text { S: }\end{array}$ & $\begin{array}{l}\text { Good } \\
\text { Abundant, Grayish yellow green }(9-16-2) \\
\text { Grayish red brown }(3-13-2) \\
\text { Pale brown }(5-18-2)\end{array}$ \\
\hline $\begin{array}{l}\text { Glycerol-asparagine agar } \\
\text { (ISP No.5) }\end{array}$ & $\begin{array}{r}\mathrm{G}: \\
\mathrm{AM}: \\
\mathrm{R}: \\
\mathrm{S}:\end{array}$ & $\begin{array}{l}\text { Good } \\
\text { Abundant, Grayish yellow brown }(6-16-2) \\
\text { Brownish black }(3-11-1) \\
\text { Reddish brown }(2-12-4)\end{array}$ \\
\hline $\begin{array}{l}\text { Peptone-yeast extract iron agar } \\
\text { (ISP No.6) }\end{array}$ & $\begin{array}{r}\text { G: } \\
\text { AM: } \\
\text { R: } \\
\text { S: }\end{array}$ & $\begin{array}{l}\text { Poor } \\
\text { None } \\
\text { Pale yellowish brown }(7-18-3) \\
\text { None }\end{array}$ \\
\hline $\begin{array}{l}\text { Tyrosine agar } \\
\text { (ISP No.7) }\end{array}$ & $\begin{array}{r}\text { G: } \\
\text { AM: } \\
\text { R: } \\
\mathrm{S}:\end{array}$ & $\begin{array}{l}\text { Good } \\
\text { Abundant, Light olive gray }(9-17-1) \\
\text { Grayish red brown }(3-13-2) \\
\text { Reddish brown }(2-12-4)\end{array}$ \\
\hline
\end{tabular}

* Color codes from the Guide to Color Standard

Abbreviation: G, Growth; AM, Aerial mycelium; R, Reverse side color; S,

Soluble pigment 
and biological activities of them.

The producing strain TC1087 was isolated from a soil sample collected in Hiroshima City, Japan. The cultural characteristics are summarized in Table 1. The substrate mycelia developed well and were irregularly branched. Each spore chain, which was in the form of curves, hooks, or loops, had 5 to 30 or more spores per chain. The spores were oval to ellipsoidal, with size of $0.7 \sim 0.9 \times 1.5 \sim 1.8 \mu \mathrm{m}$, and the surface was smooth. Fragmentation of substrate mycelia, sporangia, or motile spores were not observed. The physiological properties and the utilization of carbon sources are summarized in Table 2. Analysis of the wholecell hydrolysates showed the presence of LL-diaminopimelic acid, indicating that the cell wall belongs to type I. On the basis of these morphological and chemotaxonomic characteristics, the strain TC 1087 was assigned to the genus Streptomyces.

The fermentation was carried out at $27^{\circ} \mathrm{C}$ in a 50 -liter jar fermentor with agitation of $200 \mathrm{rpm}$ and aeration at 15 liters per minute by using 30 liters of a medium composed of $1.0 \%$ glucose, $4.0 \%$ dextrin, $2.5 \%$ Bactosoytone, $0.1 \%$ yeast extract, $0.3 \% \mathrm{CaCO}_{3}, 0.01 \%$ defoaming agent $(\mathrm{CC}$ 438; NIPPON OIL \& FAT CO., LTD.), adjusted at $\mathrm{pH} 7.0$ before autoclaving. The inhibitory activity of the fermentation broth against $20 \mathrm{~S}$ proteasome was found after 48 hours of cultivation and reached maximum after 120 hours.

The broth filtrate (27 liters) was applied to a Diaion HP20 column and eluted with $50 \%$ aqueous methanol. The eluate was concentrated and subjected to a mediumpressure reverse-phase silica gel column chromatography
(MPLC, YMC ODS A60), followed by elution with $10 \%$ aqueous acetonitrile. The active eluate was concentrated and rechromatographed on a silica gel MPLC (Wako gel C300) developed with $\mathrm{CH}_{2} \mathrm{Cl}_{2}-\mathrm{MeOH}(7: 1)$ to afford semi-pure TMC-89s (560 mg). The semi-pure TMC-89s were purified by preparative HPLC (column: YMC DODS-5B $(30 \mathrm{~mm} \times 250 \mathrm{~mm})$, mobile phase: acetonitrile water $(12: 88)$, flow rate: $25 \mathrm{ml} /$ minute, detection: UV

Table 2. Physiological properties of strain TC 1087.

\begin{tabular}{lc}
\hline Characteristic & TC 1087 \\
\hline Temperature range for growth (ISP No. 2) & $25 \sim 45^{\circ} \mathrm{C}$ \\
Optimum temperature for growth (ISP No. 2) & $25 \sim 37^{\circ} \mathrm{C}$ \\
Formation of melanoid pigment & - \\
$\quad$ ISP No.6 & \pm \\
ISP No.7 & \pm \\
Liquefaction of gelatin & - \\
Coagulation of milk & + \\
Peptonization of milk & + \\
Hydrolysis of starch & - \\
Decomposition of cellulose & - \\
Reduction of nitrate & $6 \%$ \\
NaCl tolerance (ISP No. 2) & \\
Utilization of carbon source & + \\
L-Arabinose & + \\
D-Fructose & + \\
D-Glucose & \pm \\
Inositol & + \\
D-Mannitol & - \\
Raffinose & + \\
L-Rhamnose & - \\
Sucrose & + \\
D-Xylose & \\
\hline
\end{tabular}

+ , Positive; \pm , doubtful; -, negative.

Table 3. Physico-chemical properties of TMC-89A and B.

\begin{tabular}{lll}
\hline & TMC-89A & TMC-89B \\
\hline Appearance & White powder & White powder \\
MP (dec.) & $99^{\circ} \mathrm{C}$ & $97^{\circ} \mathrm{C}$ \\
{$[\alpha]_{D}{ }^{20}$} & $-7.7^{\circ}\left(c 0.3, \mathrm{H}_{2} \mathrm{O}\right)$ & $-6.8^{\circ}\left(c 0.3, \mathrm{H}_{2} \mathrm{O}\right)$ \\
Molecular formula & $\mathrm{C}_{21} \mathrm{H}_{36} \mathrm{~N}_{4} \mathrm{O}_{9}$ & $\mathrm{C}_{21} \mathrm{H}_{36} \mathrm{~N}_{4} \mathrm{O}_{9}$ \\
FAB-MS $(m / z)$ & $489(\mathrm{M}+\mathrm{H})^{+}, 511(\mathrm{M}+\mathrm{Na})^{+}$ & $489(\mathrm{M}+\mathrm{H})^{+}, 511(\mathrm{M}+\mathrm{Na})^{+}$ \\
HR-FAB-MS $(m / z)$ & & \\
$\quad$ & 511.2350 & 511.2355 \\
$\quad$ Found & 511.2382 & 511.2382 \\
Calcd. & for $\mathrm{C}_{21} \mathrm{H}_{36} \mathrm{~N}_{4} \mathrm{O}_{9} \mathrm{Na}$ & for $\mathrm{C}_{21} \mathrm{H}_{36} \mathrm{~N}_{4} \mathrm{O}_{9} \mathrm{Na}$ \\
& End absorption & End absorption \\
UV $\lambda_{\max }(\mathrm{MeOH})$ & $3300,3070,2970,2900$, & $3300,3070,2960,2940$, \\
IR $v_{\max }(\mathrm{KBr}) \mathrm{cm}^{-1}$ & $1720,1640,1530,1460$, & $1720,1640,1530,1460$, \\
& $1380,1260,1220,1045$ & $1380,1340,1220,1045$ \\
& & \\
Solubility & $\mathrm{H}_{2} \mathrm{O}, \mathrm{DMSO}, \mathrm{MeOH}$ & $\mathrm{H}_{2} \mathrm{O}, \mathrm{DMSO}, \mathrm{MeOH}$ \\
$\quad$ soluble in & $\mathrm{CHCl}_{3}$, EtOAc, $n$-hexane & $\mathrm{CHCl}_{3}, \mathrm{EtOAc}, n$-hexane \\
\hline insoluble in & & \\
\hline
\end{tabular}


Table 4. ${ }^{1} \mathrm{H}$ and ${ }^{13} \mathrm{C}$ NMR data of TMC-89A and B.

\begin{tabular}{|c|c|c|c|c|}
\hline \multirow{2}{*}{ Position } & \multicolumn{2}{|c|}{ TMC-89A } & \multicolumn{2}{|c|}{ TMC-89B } \\
\hline & $\delta_{\mathrm{C}}{ }^{2}$ & $\delta_{\mathrm{H}}^{\mathrm{b}}$ & $\delta_{\mathrm{C}}^{\mathrm{a}}$ & $\delta_{\mathrm{H}}^{\mathrm{b}}$ \\
\hline \multirow[t]{2}{*}{1} & $47.9(t)^{c}$ & $3.05(1 \mathrm{H}, \mathrm{d}, 5.4)^{\mathrm{d}}$ & $47.9(\mathrm{t})$ & $3.04(1 \mathrm{H}, \mathrm{d}, 5.4)$ \\
\hline & & $3.07(1 \mathrm{H}, \mathrm{d}, 5.4)$ & & $3.07(1 \mathrm{H}, \mathrm{d}, 5.4)$ \\
\hline 2 & $62.9(\mathrm{~s})$ & & $62.9(\mathrm{~s})$ & \\
\hline 3 & $206.7(\mathrm{~s})$ & & $206.6(\mathrm{~s})$ & \\
\hline 4 & $50.4(d)$ & $4.38(1 \mathrm{H}, \mathrm{m})$ & $50.4(\mathrm{~d})$ & $4.37(1 \mathrm{H}, \mathrm{m})$ \\
\hline \multirow[t]{2}{*}{5} & $37.0(t)$ & $1.25(1 \mathrm{H}, \mathrm{m})$ & $37.0(t)$ & $1.26(1 \mathrm{H}, \mathrm{m})$ \\
\hline & & $1.44(1 \mathrm{H}, \mathrm{m})$ & & $1.44(1 \mathrm{H}, \mathrm{m})$ \\
\hline 6 & $24.4(\mathrm{~d})$ & $1.67(1 \mathrm{H}, \mathrm{m})$ & $24.3(\mathrm{~d})$ & $1.67(1 \mathrm{H}, \mathrm{m})$ \\
\hline 7 & $23.1(q)$ & $0.89(3 \mathrm{H}, \mathrm{d}, 6.6)$ & $23.1(q)$ & $0.89(3 \mathrm{H}, \mathrm{d}, 6.6)$ \\
\hline \multirow[t]{2}{*}{8} & $59.7(\mathrm{t})$ & $3.31(1 \mathrm{H}, \mathrm{dd}, 5.2,12.4)$ & $59.7(t)$ & $3.33(1 \mathrm{H}, \mathrm{dd}, 5.4,12.4)$ \\
\hline & & $4.12(1 \mathrm{H}, \mathrm{dd}, 6.4,12.4)$ & & $4.11(1 \mathrm{H}, \mathrm{dd}, 6.5,12.4)$ \\
\hline 9 & $20.8(q)$ & $0.84(3 \mathrm{H}, \mathrm{d}, 6.6)$ & $20.8(q)$ & $0.83(3 \mathrm{H}, \mathrm{d}, 6.6)$ \\
\hline 1 & $169.8(\mathrm{~s})$ & & $169.9(\mathrm{~s})$ & \\
\hline 2 & 57.7 (d) & $4.33(1 \mathrm{H}, \mathrm{dd}, 5.5,8.6)$ & $57.9(\mathrm{~d})$ & $4.30(1 \mathrm{H}, \mathrm{m})$ \\
\hline $3^{\prime}$ & $66.6(\mathrm{~d})$ & $3.95(1 \mathrm{H}, \mathrm{m})$ & $66.6(d)$ & $3.93(1 \mathrm{H}, \mathrm{m})$ \\
\hline $4^{\prime}$ & $18.7(q)$ & $1.02(3 \mathrm{H}, \mathrm{d}, 6.9)$ & $18.8(q)$ & $1.03(3 \mathrm{H}, \mathrm{d}, 6.5)$ \\
\hline $1 "$ & $169.4(\mathrm{~s})$ & & $169.7(\mathrm{~s})$ & \\
\hline $2 "$ & $57.4(\mathrm{~d})$ & $4.35(1 \mathrm{H}, \mathrm{m})$ & $57.8(d)$ & $4.29(1 \mathrm{H}, \mathrm{m})$ \\
\hline $3 "$ & $66.7(\mathrm{~d})$ & $3.91(1 \mathrm{H}, \mathrm{m})$ & $66.2(\mathrm{~d})$ & $4.04(1 \mathrm{H}, \mathrm{m})$ \\
\hline $4 "$ & $18.7(q)$ & $1.04(3 \mathrm{H}, \mathrm{d}, 6.7)$ & $19.0(q)$ & $1.05(3 \mathrm{H}, \mathrm{d}, 6.5)$ \\
\hline $1^{\prime \prime}$ & $170.1(\mathrm{~s})$ & & $170.7(\mathrm{~s})$ & \\
\hline $2 " \prime$ & $46.2(\mathrm{~d})$ & $3.27(1 \mathrm{H}, \mathrm{q}, 7.1)$ & $45.9(\mathrm{~d})$ & $3.35(1 \mathrm{H}, \mathrm{q}, 7.1)$ \\
\hline 3"' & $172.2(\mathrm{~s})$ & & $172.9(\mathrm{~s})$ & \\
\hline $4 "$ & 14.7 (q) & $1.17(3 \mathrm{H}, \mathrm{d}, 7.1)$ & $14.6(q)$ & $1.20(3 \mathrm{H}, \mathrm{d}, 7.1)$ \\
\hline $4-\mathrm{NH}$ & & $8.07(1 \mathrm{H}, \mathrm{d}, 7.3)$ & & $7.92(1 \mathrm{H}, \mathrm{d}, 7.1)$ \\
\hline $8-\mathrm{OH}$ & & $5.25(1 \mathrm{H}, \mathrm{dd}, 5.2,6.4)$ & & $5.02(1 \mathrm{H}, \mathrm{dd}, 5.4,6.5)$ \\
\hline $2^{\prime}-\mathrm{NH}$ & & $7.73(1 \mathrm{H}, \mathrm{d}, 8.5)$ & & $7.88(1 \mathrm{H}, \mathrm{d}, 8.5)$ \\
\hline $3-\mathrm{OH}$ & & $4.70(1 \mathrm{H}, \mathrm{d}, 5.1)$ & & $4.70(1 \mathrm{H}, \mathrm{d}, 5.0)$ \\
\hline $2 "-\mathrm{NH}$ & & $7.91(1 \mathrm{H}, \mathrm{d}, 8.2)$ & & $8.04(1 \mathrm{H}, \mathrm{d}, 7.8)$ \\
\hline 3"-OH & & $5.07(1 \mathrm{H}, \mathrm{d}, 4.7)$ & & $5.07(1 \mathrm{H}, \mathrm{d}, 4.6)$ \\
\hline 3"'-NH & & 7.03 (1H. br-s) & & $7.13(1 \mathrm{H}, \mathrm{br}-\mathrm{s})$ \\
\hline 3"'-NH & & $7.36(1 \mathrm{H}, \mathrm{br}-\mathrm{s})$ & & $7.43(1 \mathrm{H}$, br-s $)$ \\
\hline
\end{tabular}

${ }^{a} 100 \mathrm{MHz}$ in DMSO- $d_{6}$

${ }^{\mathrm{b}} 400 \mathrm{MHz}$ in DMSO- $d_{6}$

${ }^{\mathrm{C}}$ Multiplicity.

${ }^{d}$ Proton number, multiplicity and coupling constants in $\mathrm{Hz}$.

absorption at $210 \mathrm{~nm}$ ). TMC-89A was eluted at the retention time of 27 minutes, followed by TMC-89B at 31 minutes. The appropriate eluates were pooled, concentrated and further purified by Sephadex LH-20 column chromatography with methanol, yielding pure TMC-89A $(126 \mathrm{mg})$ and TMC-89B (61 mg).

The physico-chemical properties of TMC-89A and B are summarized in Table 3. The molecular formula of TMC$89 \mathrm{~A}$ and $\mathrm{B}$ was determined as $\mathrm{C}_{21} \mathrm{H}_{36} \mathrm{~N}_{4} \mathrm{O}_{9}$ on the basis of their HR-FAB-MS and ${ }^{1} \mathrm{H}$ and ${ }^{13} \mathrm{C}$ NMR spectral data. Their IR spectra exhibited the presence of hydroxyl $\left(3300 \mathrm{~cm}^{-1}\right)$, ketone or ester $\left(1720 \mathrm{~cm}^{-1}\right)$, and amide $(1640$ and $1530 \mathrm{~cm}^{-1}$ ) groups. The NMR spectral data of TMC$89 \mathrm{~A}$ and $\mathrm{B}$ are summarized in Table 4. The structure of TMC-89A was determined by the analyses of the NMR experiments such as ${ }^{1} \mathrm{H}-{ }^{1} \mathrm{H}$ COSY, NOESY, HMQC and $\mathrm{HMBC}$, and MS spectrum (Fig. 1), along with the degradation studies. The HMBC correlations from $\mathrm{C}-1^{\prime \prime \prime}(\delta$ $170.1)$ to $4^{\prime \prime \prime}-\mathrm{H}(\delta 1.17)$; $\mathrm{C}-3^{\prime \prime \prime}(\delta 172.2)$ to $4^{\prime \prime \prime}-\mathrm{H}$ and $3^{\prime \prime \prime}-$ $\mathrm{NH}_{2}(\delta 7.03,7.36)$, and the NOEs observed between $2^{\prime \prime \prime}-\mathrm{H}$ $\left(\begin{array}{ll}\delta & 3.27\end{array}\right)$ and $3^{\prime \prime \prime}-\mathrm{NH}_{2} ; \quad 2^{\prime \prime \prime}-\mathrm{H}$ and $2^{\prime \prime}-\mathrm{NH}\left(\begin{array}{ll}\delta & 7.91\end{array}\right)$ demonstrated the structure of $\mathrm{C}-1^{\prime \prime \prime}$ to $3^{\prime \prime \prime}-\mathrm{NH}_{2}$, which was attached to $2^{\prime \prime}-\mathrm{NH}$. The remaining sequence of TMC-89A was confirmed by EI-MS spectrum as shown in Fig. 1. The 
Fig. 1. 2D-NMR and EI-MS fragmentation of TMC-89A.

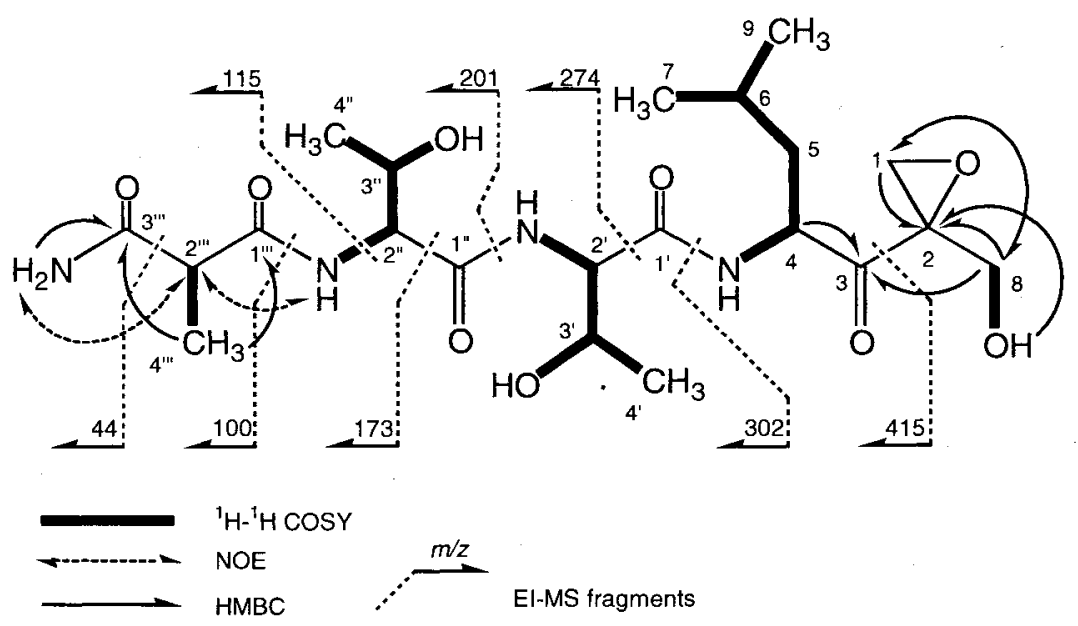

Fig. 2. The structures of TMC-89A and B.<smiles>CC(C)CC(NC(=O)[C@H](NC(=O)[C@@H](NC(=O)[C@@H](C)C(N)=O)C(C)O)C(C)O)C(=O)C1(CO)CO1</smiles>

NMR data of TMC-89B was almost identical to that of TMC-89A except for the slight shifts of $\mathrm{C}-1^{\prime \prime \prime} \sim \mathrm{C}-3^{\prime \prime \prime}$ signals (Table 4). No difference, however, was observed in the MS data of them. Therefore, TMC-89B was considered to be a stereoisomer of TMC-89A. Acid hydrolysis of TMC-89A and $\mathrm{B}$ with $6 \mathrm{~N} \mathrm{HCl}$ gave one spot of L-threonine as analyzed by chiral TLC. Thus, the stereochemistries of $\mathrm{C}-2^{\prime}, \mathrm{C}-3^{\prime}, \mathrm{C}-2^{\prime \prime}$, and $\mathrm{C}-3^{\prime \prime}$ were assigned to $S, R, S$, and $R$, respectively (Fig. 2). In order to confirm the stereochemistry of C-2"' of TMC-89A and B, the carboxamide group $\left(\mathrm{C}-3^{\prime \prime \prime}-\mathrm{NH}_{2}\right)$ was reduced to an amine group by [bis(trifluoroacetoxy)iodo]benzene ${ }^{9)}$. Acid hydrolysis of each reduced product of TMC-89A and B gave L-alanine and D-alanine, respectively, along with
Table 5. Inhibitory activities of TMC-89A, B and ALLN against the ChT-L, T-L, and PGPH activities of $20 \mathrm{~S}$ proteasome.

\begin{tabular}{lccc}
\hline \multirow{2}{*}{ Compound } & \multicolumn{3}{c}{$\mathrm{IC}_{50}(\mu \mathrm{M})$} \\
\cline { 2 - 4 } & ChT-L & T-L & PGPH \\
\hline TMC-89A & 1.1 & 0.39 & 7.2 \\
TMC-89B & 1.1 & 0.51 & 7.1 \\
ALLN & 6.6 & 6.0 & 21 \\
\hline
\end{tabular}


Table 6. Cytotoxicities of TMC-89A and B against tumor cells in vitro.

\begin{tabular}{lcc}
\hline \multirow{2}{*}{ Cell line } & \multicolumn{2}{c}{$\mathrm{IC}_{50}(\mu \mathrm{M})$} \\
\cline { 2 - 3 } & $\mathrm{TMC}-89 \mathrm{~A}$ & $\mathrm{TMC}-89 \mathrm{~B}$ \\
\hline HCT-116 human colon carcinoma & $>20$ & $>20$ \\
HeLa S3 human epitheloid carcinoma & $>20$ & $>20$ \\
SK-BR-3 human breast adenocarcinoma & 12 & 13 \\
WiDr human colon adenocarcinoma & $>20$ & $>20$ \\
HL-60 human promyelocytic leukemia & 13 & 12 \\
B-16 murine melanoma & 8.2 & 7.6 \\
P388D1 murine lymphoid neoplasm & $>20$ & $>20$ \\
\hline
\end{tabular}

L-threonine by the chiral TLC analyses. Thus, the configurations of C-2"' of TMC-89A and B were determined to be $R$ and $S$, respectively (Fig. 2).

$20 \mathrm{~S}$ proteasome has three catalytic subunits and shows at least three distinct peptidase activities, chymotrypsine-like (ChT-L), trypsin-like (T-L), and peptidylglutamyl-peptide hydrolyzing (PGPH) activities, which cleave peptide bonds on carboxyl side of hydrophobic, basic, and acidic amino acids, respectively ${ }^{10)}$. The inhibitory activities of TMC89A, B and $\mathrm{N}$-Acetyl-Leu-Leu-nLeu-CHO (ALLN) against the ChT-L, T-L, and PGPH activities are shown in Table 5. TMC-89A and B inhibited the T-L activity much stronger than TMC-86s and TMC-96, while all these compounds inhibited the ChT-L and PGPH activities to a similar extent. The same inhibitory activities of TMC-89A as TMC-89B indicated that the stereochemistry of $\mathrm{C}-2$ "' was not vital to their activities. TMC-89A and B did not inhibit m-calpain, cathepsin $\mathrm{L}$, and trypsin at $100 \mu \mathrm{M}$, suggesting their high specificity for $20 \mathrm{~S}$ proteasome. TMC-89A and B did not show remarkable cytotoxicities to various tumor cell lines (Table 6).

\section{Experimental}

\section{Enzyme Assays}

20S proteasome was isolated from THP.1 monocytic cells ${ }^{5)}$. Other enzymes were purchased from commercial sources. The activities of enzymes were measured by using fluorescence substrates according to the method reported previously ${ }^{5}$.

\section{Cytotoxic Assays}

Cells were incubated with a test sample at $37^{\circ} \mathrm{C}$ for 72 hours in culture medium, and their viability was determined by the tetrazolium or neutral red assay method ${ }^{5)}$.

\section{Reduction of the Carboxamide Group}

TMC-89A $(4.2 \mathrm{mg})$ was dissolved in $0.5 \mathrm{ml}$ of $\mathrm{CH}_{3} \mathrm{CN}$ $\mathrm{H}_{2} \mathrm{O}(1: 1)$. A solution of [bis(trifluoroacetoxy)iodo]benzene ( $9 \mathrm{mg}$ in $0.1 \mathrm{ml} \mathrm{CH}_{3} \mathrm{CN}$ ) was added, and the mixture was stirred for 6 hours under $\mathrm{N}_{2}$ atmosphere. The solvent $\left(\mathrm{CH}_{3} \mathrm{CN}\right)$ was evaporated in vacuo. The resultant liquid was acidified with $6 \mathrm{~N} \mathrm{HCl}$, and washed with ether $(1 \mathrm{ml})$. The water layer was concentrated to dryness and hydrolyzed with $0.2 \mathrm{ml}$ of $6 \mathrm{~N} \mathrm{HCl}$ in a sealed tube $\left(110^{\circ} \mathrm{C}, 16\right.$ hours). The hydrolysate was analyzed by chiral TLC (HPTLCCHIR, Merck) with a solvent of $\mathrm{MeOH}-\mathrm{H}_{2} \mathrm{O}-\mathrm{CH}_{3} \mathrm{CN}$ $(1: 1: 4)$. Rf; L-alanine: 0.48 , D-alanine: 0.44 , L-threonine: 0.57 , D-threonine: 0.52 .

\section{Acknowledgments}

We are grateful to thank Ms. NAOKo FUKUI, Dr. Noriko OHASHI, and Ms. SONOKO SHINA for measuring spectra. We thank Mr. Kimio KaWANo and Ms. Mreko KoITABashi for determination of cytotoxicities. We also thank Mr. KouzoU Yamamoto, Mr. NobUyUki OKada, Mr. AKIRA TAKaBAYashi, and Mr. NORIAKI KAMEDA for their excellent technical 
assistance.

\section{References}

1) Ciechanover, A. \& A. L. Schwartz: The ubiquitinproteasome pathway: The complexity and myriad functions of proteins death. Proc. Natl. Acad. Sci. USA 95: 2727 2730, 1998

2) Palombella, V. J.; O. J. Rando, A. L. Goldberg \& T. MANIATIS: The ubiquitin-proteasome pathway is required for processing the NF- $\mathrm{KB} 1$ precursor protein and the activation of NF- $\kappa \mathrm{B}$. Cell 78: 773 785, 1994

3) Rock, K. L.; C. Gramm, L. Rothstein, K. Clark, R. Stein, L. Dick, D. Hwang \& A. L. Goldberg: Inhibitors of the proteasome block the degradation of most cell proteins and the generation of peptides presented on MHC class I molecules. Cell 78: 761 771, 1994

4) He, H.; X. M. Qi, J. Grossmann \& C. W. Distelhorst: c-Fos degradation by the proteasome. An early, Bcl-2regulated step in apoptosis. J. Biol. Chem. 273: 25015 25019, 1998

5) Koguchi, Y.; J. Kohno, S. Suzuki, M. Nishio, K. Takahashi, T. OhnuKi \& S. Komatsubara: TMC-86A, $\mathrm{B}$ and TMC-96, new proteasome inhibitors from Streptomyces sp. TC 1084 and Saccharothrix sp. TC1094. I. Taxonomy, fermentation, isolation, and biological activities. J. Antibiotics 52: 1069 1077, 1999
6) Koguchi, Y.; J. Kohno, S. Suzuki, M. Nishio, K. TAKahashi, T. OHnuki \& S. Komatsubara: TMC-86A, $\mathrm{B}$ and TMC-96, new proteasome inhibitors from Streptomyces sp. TC 1084 and Saccharothrix sp. TC1094. II. Physico-chemical properties and structure elucidation. J. Antibiotics 53: 63 65, 2000

7) Koguchi, Y.; J. Kohno, S. SuzuKi, M. Nishio, K. Takahashi, T. Ohnuki \& S. Komatsubara: TMC-95A, $\mathrm{B}, \mathrm{C}$, and $\mathrm{D}$, novel proteasome inhibitors produced by Apiospora montagnei Sacc. TC 1093. Taxonomy, production, isolation, and biological activities. J. Antibiotics 53: 105 109, 2000

8) Kohno, J.; Y. Koguchi, M. Nishio, K. Takahashi, T. OKuda, T. OHNuki \& S. Komatsubara: Structures of TMC-95 A, B, C and D: Novel proteasome inhibitors from Apiospora montagnei Sacc. TC 1093. J. Org. Chem. 65: 990 995, 2000

9) F.-Zakuski, M. C.; E. L.-Soroca, J. Devin \& B. P. ROQUES: ${ }^{1} \mathrm{H}$ NMR configurational correlation for retroinverso dipiptides: application to the determination of the absolute configuration of "enkephalinase" inhibitors. Relationships between stereochemistry and enzyme recognition. J. Med. Chem. 29: 751 757, 1986

10) Orlowski, M. \& C. Michaud: Pituitary multicatalytic proteinase complex. Specificity of components and aspects of proteolytic activity. Biochemistry 28: 9270 9278,1989 